\title{
On methods of coverage of sociopolitical aspects of urban development by social disciplines
}

\author{
Igor Andreev"1,* \\ ${ }^{1}$ Moscow State University of Civil Engineering, Yaroslavskoye shosse, 26, Moscow, 129337, Russia
}

\begin{abstract}
The author has identified a trend towards the politicization of urban planning in Russia, caused by a set of factors. The author believes that students should be timely taught to adequately respond to the attempts of the leading political parties and movements to influence the urban planning industry. These attempts represent the imposition of particular urban plans for their benefit, the resolution of urban planning conflicts in the best interests of particular parties, etc. According to the author, who has accumulated an extensive lecturing experience, this goal is attainable by offering social disciplines, including Sociology, Sociology of Urban Development, Bases of Social Regulation and Public Relations, to bachelor students, majoring in urban planning at the Moscow State University of Civil Engineering. The author has considered several issues of teaching methods, in particular, he has identified the list of political problems to be analyzed and the type of classes to be organized, etc. In the report, the author makes a conclusion that the focus on the sociopolitical aspects of urban planning in the courses of social disciplines improves the students' understanding of the nature of urban planning as a democratic practice.
\end{abstract}

\section{Introduction}

Urban development has traditionally been viewed as a key matter of dispute between versatile Russian political parties and movements. The significance of this dispute is driven by the pending housing problem, which is deemed utterly sensitive, because Russia has been far behind industrially developed countries both in terms of the amount of the housing space per capita and the housing quality. Recently, problems of (1) disparity between the pace of development and the quality of the urban environment in towns, demonstrating different population figures and economic environments, (2) selection of the most optimal organizational and legal frameworks for the housing renovation, and (3) concerns, expressed by versatile social groups of urban residents within the framework of the urban planning policy. The multi-ethnic composition of construction teams raises the importance of challenges, associated with the need to terminate the extremists' attempts to get migrant workers, originating from Central Asia and some Russian regions, involved in illegal activities of religious origin.

* Corresponding author: andreev-i-v@yandex.ru 
Political parties and movements, capable of demonstrating the most convincing answers to their electors, have a strong potential to enlarge their political influence and obtain access to resources of power. Therefore, political parties do their best to raise awareness of citizens about their solutions to urban planning problems; they do it not only at the time of election campaigns, rather, they expend efforts on the ongoing basis; they employ media agencies, use public hearings as instruments, make public outreach efforts, etc.

These actions have proven the need to improve methods of coverage of sociopolitical aspects of urban development by civil engineering universities and sociological disciplines that they deliver. Future specialists will need this knowledge to optimize interpersonal relations within their teams, to generate arguments in case of disputes with protesters attacking construction sites, and to take a better account of social expectations in the process of urban planning.

The author believes that the curriculum, developed for bachelor students, majoring in urban development at the Institute of Construction and Architecture of the Moscow State University of Civil Engineering (MSUCE), offers excellent opportunities to learn more about social and political aspects of urban planning and building activities. This curriculum contemplates the consecutive study of Sociology, Sociology of Urban Development and Bases of Social Regulation and Public Relations by freshmen and sophomores. We believe that this feature demonstrates that university executives have a deep understanding of the nature of the work, performed by urban planners. His or her scope of responsibilities is highly diverse, and it encompasses the influence of versatile factors of technological, cultural, sociopolitical, and psychological origin. It is noteworthy that the curriculum, developed for the Urban Development speciality at MSUCE, has a high number of academic hours, allocated to social and humanitarian disciplines. In particular, the number of academic hours, allocated to sociology and psychology within the framework of this speciality, quadruples the number of academic hours, allocated to specialities, offered to students, majoring in Industrial/Civil Engineering and Thermal Power Engineering. (It is noteworthy that the curriculum of urban development majors has no Political Science at all.)

In $2014-2017$, the author of this report delivered lectures and practical classes to urban development students, majoring in each of the above three disciplines. He also developed (and co-authored) work programmes, drafted compendiums of lectures, methodological recommendations and workbooks, designated for practical classes. Therefore, the author has accumulated some particular experience, which helps him to formulate the following research goals of this report:

- To define the content of the structural components of social disciplines, covering the sociopolitical aspects of urban development;

- To highlight the experience of application of the most successful methodical techniques associated with the delivery of respective disciplines;

- To demonstrate the nature of students' perception of this information and to assess their performance.

\section{Literature review}

The author found valuable material on social and political aspects of town-planning policy in works by A. Vanolo [1], T. Monfaredzadeh and R. Krueger [2], C. Wan, G. Qiping Shen and S. Choi [3], P. Boland, J. Bronte and J. Muir [4], Y. Depietri, G. Kallis, F. Baró and C. Cattaneo [5], S. Hossain, W. Scholz and S. Baumgart [6]. The author used to develop the courses works on public relations by R.L. Heath [7], S.C. Duhé [8], A.A. Betteke van Ruler and D. Verĉiĉ [9]. Source of information about the specific views of various political parties of Russia on the prospects of development of urban areas are pre-election programs of their federal and regional leaders, other party documents [10-13]. 


\section{Methods}

The methods employed in the course of this research were designated to: (1) identify the extent of students' willingness to study sociopolitical aspects of urban development; (2) assess the percentage of the course material successfully learned by the students.

Goal (1) contemplated the employment of a questionnaire survey, whereby students answered questions (a) about the significance of the new knowledge for their future professional activities, (b) about the sociopolitical information that was missing from their course materials, and (c) about their satisfaction with the teaching methods, etc.

Goal (2) contemplated (a) the assessment of the quality of student assignments, performed at practical classes; (b) the assessment of tests completed by students upon the delivery of each section of the discipline; (c) the joint assessment of the reports, delivered at science conferences, drafted by students in cooperation with their lecturers, and (d) the extent of implementation of particular roles in the course of business simulation activities; (e) the final academic assessment of students.

\section{Results}

The above-listed social disciplines to be mastered by the urban development students, are delivered in the following sequence: Sociology (year 1, semester 1); Sociology of Urban Development (year 1, semester 2); Bases of Social Regulation and Public Relations (year 2, semester 1). This sequence helps lecturers to move from the «abstract to concrete» logic and to gradually shift the teaching focus from theory to practice in respect of the practical skills, which will help future specialists to respond to political challenges arising in the course of his/her future professional career.

Sociology. The first stage of the students' mastering sociopolitical aspects of urban development consists in their learning political sociology as part of their Sociology course. The areas of knowledge, which will navigate students to the issues of particular interest, consist in problems of political power, political system and political ideology.

We would recommend lecturers to draw students' attention to the fact that any support, extended by the population to the political course formulated by the ruling political elite or parties/movements, is significantly driven by their successful town planning activities, performed in compliance with social anticipations, including new and original patterns for urban environments. This statement can be successfully verified at regional and municipal levels. As known, problems of town-planning and transportation are at the top of the candidates' agendas, as far as elections to regional and local self-government authorities are concerned.

As for the political system, the author finds it expedient to focus on the status, structure and powers of government and local self-government authorities, including those responsible for town planning.

Whenever lecturers consider the issue of political ideology, they offer an overview of the main contemporary ideological and political trends (neoconservatism, social democracy, liberalism, etc.) It is necessary to make it clear what ideological systems form the conceptual basis of programmes, developed by the most influential Russian political parties. The lecturer should also draw the students' attention (yet in the most general way!) to the fact that diverse ideological preferences of political parties serve as the basis for their diverse approaches to key aspects of urban planning activities (the state regulation to private initiative ratio in the construction industry, monopolization policy versus de-monopolization of the construction services market, approaches towards the resolution of the problem of housing for low-income residents, attitude towards ghettoization of the urban space, etc.). 
Therefore, having completed a sociology course, students will have a general idea of (a) the importance of urban planning problems for the development of social resources by the political authorities and for the successful competition with other parties, (b) ideological benchmarks, and (c) legal powers attained by versatile contributors to urban planning processes.

Sociology of Urban Development. Whenever a lecturer delivers a first unit of this course, entitled «The city as a specific type of the social space», he or she has an opportunity to initiate students into basic socio-psychological features of urban residents and social groups, identifiable within the urban structure. This information serves as the basis for the understanding of the features of any political involvement, demonstrated by urban residents, and of the methods, employed by political parties and movements to bring various categories of urban residents to their side.

In particular, «Urbanism as a Way of Life» by L. Wirth serves as a helpful means of delivering this subject matter into the classroom. This work reveals the dialectic of atomization and isolation of urban groups, on the one hand, and consolidation of the urban population, on the other hand [14, str. 93-118]. The lecturer should explain that spatial segregation of urban residents by their race and ethnicity, social and economic statuses preconditions the political preferences, demonstrated by residents of different urban districts. According to L. Wirth, highly competitive environments, the pursuit of personal success and uniqueness promoted by cities, novelty and eccentricity of human activities represent the most important features of the urban political lifestyle.

These phenomena are implemented in a variety of outdoor political actions, in the form and content of printed agitation materials, in the visual propaganda, etc. L. Wirth believes that the multiplicity of interests, expressed by urban residents, associated with different aspects of their social life and implemented in their activities within versatile public organizations and movements, represents an important feature of the urban lifestyle. The lecturer should draw the students' attention to the fact that this feature preconditions the complexity of political spaces of cities and towns, because in particular contexts, urban movements, aimed at environmental protection, protection of the historic legacy, consumers' rights, revival of national cultures typical for particular ethnicities may accrue a certain political complexion.

This course unit may also require the study of the collective monograph «The Fight for an Urban Resident» prepared under the editorship of A.A. Vysokovsky. Its authors explain the breakdown of contemporary urban residents into four basic groups by the certain criteria, including values and environments [15]. In the course of their practical classes, students should express their ideas in terms of the forms and goals of political involvement chosen by the representatives of the above-mentioned urban groups.

The course unit entitled «The social ecology of urban planning» offers an opportunity to study the political aspects of any urban planning activities by comparing the assessments of the urban environment, made by the leading Russian political parties. Oppositional political parties often speak about the purporting policy of «de-ecologization», pursued by the leading elite and aimed at setting the stage for maximal profits to be obtained regardless of the cost. The inevitable consequence of this trend consists in the disregard of the basic public need for the preservation of the optimal ecological environment. This trend reduces the state funding of environmental programmes, weakens the environmental control exercised by the government, etc. [10, str. 20;11, str. 206-209]. At the same time, the lecturer draws the students' attention to the «Ecology of Russia» project, developed by the "United Russia» party. This project contemplates (1) the monitoring of application of the industrial/household waste management legislation, (2) promotion of ecological travelling clusters, (3) organization of environmental protection classes at secondary schools, (4) involvement of schoolchildren into «green campaigns», or actions aimed at the planting of trees and plants 
in populated localities. The project managers urge (1) for the compilation of an ecological welfare rating for the Russian regions, and (2) for the enhancement of the role of the public opinion in the process of scheduling nature protection actions [13].

We consider it expedient to introduce a practical class to be composed of students' reports covering the approaches of the leading Russian political parties towards the assessment of the environmental condition of the Russian cities and towns and their suggestions aimed at its improvement. The lecturer should inspire the students to find out what environmental problems have emerged recently and what ecological problems represent the legacy of the past, what strengths and weaknesses environmental projects, developed by the leading parties, have, what environmental actions are implemented by the parties, and what actions remain declarative.

The course unit, entitled «The ethnological and ethno-demographic aspects of urban planning», covers the issues that cannot be ignored by the political parties due to their significance and the public sensitivity to any failures in their respect. These are the problems of migration, the poly-ethnic composition of the urban population, the religious needs of different confessions, the ghettoization of the urban space, the emergence of ethnic enclaves, and inter-ethnic conflicts.

Moscow is a city, where the above-mentioned problems have manifested themselves rather bluntly. Therefore, the lecturer can use the elections of the Moscow mayor (2013) and of the Moscow City Duma deputies (2014) as the examples illustrating the approaches of political parties towards the resolution of these problems. It is noteworthy that representatives of all political parties and independent candidates acknowledged the need to improve the migration policy in the course of their election campaigns. Mayor S. Sobyanin promised to take actions to prevent any illegal migration, to reduce the percentage of the unskilled labour in the Moscow economy, and to make migrants observe the day-to-day customs and traditions of Moscow residents, etc. [12, str. 44]. Representatives of left-wing parties, including the Communist party of the Russian Federation and «The Fair Russia», drew the attention to the social-class origin of the problem and explained its emergence by the willingness of the «dirty business community» and the «bureaucrats who protected it» to profiteer from the migrants' work. The programmes of these candidates were focused on the financial and legal vehicles, designated to force entrepreneurs and public officials to comply with the migration legislation and to reduce the number of migrant workers (to rise the insurance contributions payable by the employers of migrants; to introduce severe criminal sanctions for the violation of migrant recruiting procedures) [10, str. 12-13; 11, str. 209-211].

Here, we also believe that it is expedient to conduct a practical class for the students to deliver and discuss their reports. Student reports may contain the analysis of the proposals made by the leading political parties and aimed at the resolution of the most vital ethnological problems arising in the urban planning industry. The lecturer should draw the students' attention to (1) the specific features of migration in Russia in the context of global migration trends, (2) the unacceptability of extremist and nationalistic «responses» to the migration problem, and (3) the preferable forms of interaction with national diasporas with a view to the decriminalization of the ethnic environment and the facilitation of migrants' adaptation to the social environment of Russian cities and towns.

The final unit of the urban planning sociology course is entitled «The urban policy and urban planning management». It offers an opportunity to develop a relatively integral vision of the significance of (a) assessing any urban planning activities from the political standpoint, in general, and (b) positions taken by the leading political parties in terms of the reengineering of the urban environment, in particular. This objective is attainable by arranging a simulation exercise entitled «An election discussion». The exercise will simulate some features of partyto-party relations in the course of the preparation and conduct of elections to urban selfgovernment authorities. 
In the course of the preparation to the simulation exercise, students of each group will be broken down into teams. Each team is to do their best to make sure that their candidate wins the elections (some teams will promote «independent» candidates). Particular social statuses and social roles will be attributed to each team member. «The candidate» will take the key position within each team. «The candidate» will be the student, who is interested in politics, who is particularly smart, who has declamatory skills, and who is able to swiftly and accurately respond to sudden problems. Some team members will help «the candidate» to prepare his/her speech to be delivered at the political meeting in compliance with the main programme principles of his/her party and with account for the local features of the environment. The speech must comprise the topics, regularly covered by the election campaigns, including the analysis of the urban environment, the reformation of the urban planning and transportation policies, the creation of jobs, the improvement of the social and cultural environment, the resolution of migration-related problems, the democratization of the urban management, etc. Other team members will think of the «tricky questions», designated for other «candidates». These «tricky questions» will be based on the preidentified «weak» points in their programmes.

It is noteworthy that any business simulation triggers competing behavior styles, because it provides the audience with a chance to vote for preferable «parliamentary candidates». Therefore, student teams are to choose two or three speech writers («a sociological support group») who will address the main issues of the urban planning policy in the speech to be delivered by their leader. This information is usually made available to students in the course of their day-to-day communications, and the mission of the «sociological support group» is to reduce the objective to comprehension and systematization of this information, however, if these data are deemed insufficient, «sociologists» may employ questionnaires and interviews to acquire the missing information.

The lecturer must assume personal responsibility for the appointment of «the chairman of the pre-election meeting». The student, who will play the leading part, is to demonstrate a strong willpower, excellent organizational skills, audience control abilities and adherence to the pre-set agenda. Besides, two students should serve as the «election commission» (one of them is to be its chairman); it will be responsible for the printout of «ballot papers».

This set of preparatory assignments will serve as the basis for the success of the «Preelection meeting» simulation, which will have the following script.

1. An opening speech to be delivered by the «chairman of the pre-election meeting», in which he/she briefly introduces the candidates and informs the audience about the meeting regulations (5 minutes).

2. Addresses to be made by the candidates ( 10 minutes each); each address is to be followed by a session of questions to be asked by the audience (one minute per answer), and the chairman should inspire the audience, rather than the competing teams, to ask tricky questions of each candidate.

3. The vote should be held, and votes should be counted (10 min.)

4. The chairman should declare the voting results.

The results of the simulation should be discussed at the next practical class, and competing teams should analyze their strengths and weaknesses demonstrated both at the preparatory stage and in the course of the meeting.

Thus, after studying this discipline the students' views on socio-political aspects of urban development raise to a new level. Along with the acquisition of a relatively complete and specific information about the policies of the main political parties of Russia in the transformation of the urban environment, students master the basic skills of conducting a political debate on the subject.

Bases of Social Regulation and Public Relations. We acquaint students with the general communication theory as the following step after the introductory lessons of this dicipline. 
At the lecture students get acquainted with theories of G. Lassuell, C. Shannon and W. Weaver, V. Shram and Ch. Osgood, V. P. Morozov, P. Lazarsfeld; receive a knowledge about principal components of communicating process and the nature of communication barriers [7-9]. But this knowledge is mostly acting as a theoretical basis for mastering practical skills which are more important in this course. The latter include first of all the skills taking into account the socio-political context in the process of urban planning and design. An important role we also ascribe to the mastery of the interaction skills with different target audiences, providing positive public perceptions of the implemented urban projects.

The course offers multiple opportunities to master the subject matter. The main of them are as follows:

1. The student practice conference. It will serve as the venue where speakers can present their projects, whereby they publicize their personalized vision of the hometowns. However, the lecturer offers them to take account of/analyze the viewpoints of urban planning and transportation problems, expressed by the competing politicians in the course of local election campaigns.

Evidently, the conference has a lot in common with the aforementioned pre-election meeting simulation, although the conference has three specific features. First, at the conference, a student presents him/herself as a team member of the local city hall, the chief architect or the mayor, rather than the candidate. This is how he/she «tests» different roles. Second, at the conference, students are not obliged to advocate the position of any party; rather, their mission is to identify rational proposals, hiding in the programmes of different political parties, and to incorporate them into their projects. Third, the fact that students discuss the ways to transform their home towns at conferences, triggers a special emotional atmosphere in the course of the report delivery, and conference speakers want to adequately master the subject matter.

2. Public hearings on urban planning, a simulation. The worthwhileness of this game is caused by need «to rehearse» during the event the steps of the operational procedure which a legislator defines as an «obligatory» component for the process of town-planning projects development and implementation [16, art. 28] and where therefore future engineers-town-planners should participate on repeated occasions. We can recommend to the lecturer to emphasize the humanistic aspects of the public listening which are carried out «for respect for human right on favourable standard of living» as it is noted by a legislator [16, art. 28].

In the course of the simulation, students, acting as «representatives of local government authorities», «building customers», and «experts» brush up their skills of presenting specific urban planning projects to the audience. They should demonstrate their ability to swiftly and convincingly respond to the addresses made and questions asked by the audience, some of which play the part of the opposition, which contests any proposals made by the urban authorities. These helpful communication skills develop the ability to interact with hostile audiences and reach compromises at the final stage of the simulation, when the wording of the final document, containing the main results and agreements, is accommodated.

3. The Public Relations department of the city hall, a simulation. At the first stage of the simulation, students enhance their content analysis skills by using publications on relevant urban planning projects. At the second stage, students propose adequate methods to be employed by PR departments of city halls to respond to the addresses made by activists.

These and other forms of work are optimal logical completion of the whole process of coverage of sociopolitical aspects of urban development by social disciplines. They help students practically master the skills of implementation of various social roles necessary for the development and promotion of urban projects, including in adverse social and political context. 


\section{Discussion}

Courses of social disciplines, if focused on the sociopolitical aspects of urban planning, will improve the students' understanding of the nature of contemporary urban planning as the practice which is democratic by definition, as it contemplates versatile, inter alia, political methods for the identification of social demands and means of social control over its performance [1-6]. A lecturer should teach future urban planners to refrain from any clashes with political parties or movements and to get them involved in the search for constructive solutions to urban planning problems. Besides, lecturers should draw the students' attention to the fact that although the approaches, exercised by different political parties to urban planning, are different, some of their positions are kind of similar. The similarity of positions in respect of urban planning problems is an important symptom of their relevance and social significance. Rather, the urban planners' willingness to adequately respond to the recommendations, typical for political communications, both improves the confidence of the social environment in the authorities/the construction business community, deepens the cross-party cooperation trend, and contributes to the further stabilization of Russia's political space.

Being member of the Methodology Council at the Institute of Construction and Architecture, the author has taken advantage of several valuable recommendations regarding the social disciplines' content and teaching methods, including those concerning the focus on urban planning conflicts as a most relevant and acute phenomena of urban planning activities.

Students believe that the incorporation of sociopolitical problems of urban planning into the courses of social disciplines is very helpful. They think that the study of this scope of problems contributes to their ability to identify the urban planning concerns and expectations of different social groups. Students are sure that these skills will improve their competitive ability and professional performance. Students were particularly active and creative in their efforts to prepare for the science conferences, including those organized by their institute and university. Some of the brightest student reports were forwarded to international science conferences «Integration, Partnership, and Innovations in the Civil Engineering Science and Education»; they enjoyed excellent reviews, and they were published in collections of reports. Students are particularly keen on the preparation and staging of professional learning simulations; they also demonstrate a good knowledge of sociopolitical aspects of urban planning at their examinations, including pass-fail exams in social disciplines.

\section{Conclusions}

We suppose that the position described above allows us to state the following:

Outline of the socio-political aspects of urban development in the courses of social disciplines in MSUCE proved its value. Theoretical knowledge and practical skills received by students in the learning process allow to create in their consciousness an integral view of democratically understood processes of social planning in the town-planning area, inseparably connected to the different forms and methods of social communication.

The special importance of mastering the applied skills of the justification of urban development projects to various target audiences involves, in our opinion, certain changes in the allocation of study time between lectures and practical classes, in favor of the latter (it concerns especially the discipline «Bases of Social Regulation and Public Relations»).

A new form of studying of this problematics by students can be their part, jointly with a lecturer, in real public hearings on urban development issues, followed by a discussion on sociopolitical aspects of the event in practical classes. 


\section{References}

1. A. Vanolo, Futures, 82, 26-36 (2016)

2. T. Monfaredzadeh, R. Krueger, Procedia Eng. 118, 1112-1118 (2015)

3. C. Wan, G. Qiping Shen, S. Choi, Environmental Science a. Policy 75, 70-80 (2017)

4. P. Boland, J. Bronte, J. Muir, Cities 61, 117-127 (2017)

5. Y. Depietri, G. Kallis, F. Baró, C. Cattaneo Ecological Economics 125, 83-100 (2016)

6. S. Hossain, W. Scholz, S. Baumgart, Habitat International 48, 140-148 (2015)

7. R.L. Heath, Encyclopedia of public relations (Sage cop., Thousand Oaks, 2005)

8. S.C. Duhé, Mass media and public relations (Peter Lang cop., N.Y., 2007)

9. A.A. Betteke van Ruler, D. Verĉiĉ, Public relations and communication management in Europe: a nation-by-nation introduction to public relation theory and practice (Mouton de Gruyter, Berlin, N.Y., 2004)

10. Moskva - krasnaya. Gorod dlya zhizni: Programma kommunistov na vyborah deputatov Moskovskoj gorodskoj Dumy VI sozyva (OOO «MID», Moscow, 2014)

11. N.V. Levichev, Zharkoye holodnoye leto 2013: stat'i, vystupleniya, interv'yu: iyul' sentyabr' 2013 (Kljuch, Moscow, 2014).

12. S.S. Sobyanin, 7 prioritetov. Glavnoe - Moskva! Glavnye - Moskvichi! Predvybornaya programma kandidata v me'ry Moskvy (Moscow, 2013)

13. E'kologiya Rossii: Federal'nyj proekt vserossijskoj politicheskoj partii «Jedinaja Rossija» http://eco-rt.ru/

14. L. Virt, Izbrannyje trudy po sociologii (INION RAN, Moscow, 2005)

15. A.A. Vysokovskij, Bor'ba za gorozhanina: chelovecheskij potencial i gorodskaya sreda (NIU «Vysshaya Shkola E'konomiki», Moscow, 2014)

16. Town-planning code of the Russian Federation, http://www.cis-legislation.com 